\title{
Effects of dbcAMP on progesterone synthesis by cultured goat luteal cell subpopulations isolated from early and late luteal stage corpora lutea
}

\author{
S. Arikan ${ }^{1}$, H. Kalender ${ }^{2}$, O. Simsek ${ }^{1,3}$ \\ ${ }^{1}$ Department of Physiology, Faculty of Veterinary Medicine, University of Kirikkale, Kirikkale, Turkey. \\ ${ }^{2}$ Department of Obstetric and Reproductive Disease, Faculty of Veterinary Medicine, University of Kirikkale, \\ Kirikkale, Turkey.
}

\begin{abstract}
This research aimed to investigate the effects of dbcAMP on steroid accumulation by culturing two distinct luteal cell subpopulations isolated from early and late luteal stage corpora lutea. Cells were isolated from corpora lutea collected from eight Angora goats on either the 5th or 15th days of their estrous cycles. Cell isolation was performed by enzymatic digestion using collagenase and DNase. Isolated cells were separated into two distinct subpopulations enriched with small and large luteal cells by percoll density-gradient centrifugation. Isolated cells were stained in order to detect $3 \beta$-hydroxysteroid dehydrogenase ( $3 \beta-H S D)$. Cells stained positively for $3 \beta$-HSD activity $\left(5 \times 10^{4}\right.$ cell/well $)$ were incubated with dbcAMP in the absence or presence of 22(R)-hydroxycholesterol (22R-HC) for periods of up to 7 days. Large luteal cell enriched subpopulations produced more basal progesterone $(\mathrm{P}<0.05)$ than did the small luteal cell enriched subpopulations. Treatment of cells with 22R-HC alone induced 4.00 to 11.60 times increase in steroid synthesis depending on type of cells incubated, luteal age and days of incubation. Incubation of cells with $1 \mathrm{mM}$ dbcAMP in the absence or presence of 22R-HC induced in a significant increase $(\mathrm{P}<0.01)$ in steroid accumulation in all treated groups. In contrast, when cells are treated with low dose dbcAMP $(0.1 \mathrm{mM})$, treatment induced stimulation failed to reach significant level in most treated groups. In conclusion, although treatment of goat luteal cells with dbcAMP induces an increase in steroid accumulation, a high dose is necessary to reach significant levels. Stimulatory effect of dbcAMP on steroidogenesis maintains during long life culturing.
\end{abstract}

Keywords: cholesterol, dbcAMP, goat, luteal cells, progesterone.

\section{Introduction}

The corpus luteum is known to be a temporary endocrine gland that secretes progesterone during the luteal stage of the estrous cycle (Band et al., 1987; Arikan et al., 2010) and pregnancy (Arikan and Yigit, 2003 ) in goats. If fertilization does not occur, the corpus luteum regresses in order to allow larger ovarian follicles to mature. The corpora lutea of the goat comprises a diverse population of cells that differ in capacity of steroid synthesis and size in diameter
(O'Shea, 1987; Arikan and Yigit, 2003; Kalender and Arikan, 2007). Size distribution of luteal cells having steroidogenic activity covers a wide spectrum of sizes, ranging from 5 to $37.5 \mu \mathrm{m}$ and 5 to $45 \mu \mathrm{m}$ in diameter in cyclic (Kalender and Arikan, 2007) and pregnant goats (Arikan and Yigit, 2003), respectively. We found a linear correlation between mean cell diameter and luteal age both in cyclic and pregnancy corpora lutea (Arikan and Yigit, 2003; Kalender and Arikan, 2007). Steroidogenic luteal cells have been classified into two groups as small luteal cells and large luteal cells, based on the size measurement of cells in diameter (Chegini et al., 1984; Lei et al., 1991). The cells having steroidogenic activity can be determined by testing $3 \beta-$ HSD activity. This is due to the fact that the conversion of pregnenolone to progesterone requires $3 \beta-\mathrm{HSD}$ located largely in the endoplasmic reticulum of the luteal cells (Bao et al., 1995).

Luteal tissue also comprises non-steroidogenic cells such as macrophages, blood cells, endothelial cells and fibroblasts (O'Shea et al., 1989; Fields and Fields, 1996). It is well known that synthesis of luteal steroids requires cholesterol that can be derived either from plasma lipoproteins or de novo cellular synthesis (O'Shaughnessy and Wathes, 1985b). The predominant carrier of cholesterol in goat plasma is a high density lipoprotein (Vitic and Stevanovic, 1993). It is reported that incubation of goat and feline luteal cells with 22R$\mathrm{HC}$, a membrane permeable steroid precursor, induced a dose-dependent increment in steroid synthesis. When cells were treated with $22 \mathrm{R}-\mathrm{HC}$ alone at a concentration of $10 \mu \mathrm{g} / \mathrm{ml}$, it resulted in 4 to 11 times increases in steroid synthesis throughout 7 days of incubation (Arikan and Yigit, 2009; Arikan et al., 2010). In a study which lasted $24 \mathrm{~h}$, Brannian et al. (1995) stated that culturing of porcine luteal cells with 22R-HC $(25 \mathrm{~g} / \mathrm{ml})$ induces a 3-time increases in steroid synthesis in comparison with control cells. In a second short culturing study, Musicki et al. (1994) stated that culturing of luteal cells with 22R-HC induced in a dosedependent increment in steroid accumulation in rats when cells were incubated with 1 to $10 \mu \mathrm{g} / \mathrm{ml} 22 \mathrm{R}-\mathrm{HC}$.

It has been previously demonstrated that incubation of dispersed luteal cells with dbcAMP, which is a membrane-permeable cAMP analogue, stimulates progesterone synthesis in bovine (O'Shaughnessy and Wathes, 1985a; Grazul-Bilska et al., 1996), rat (Tekpetey and Armstrong 1991), human (Carrascol et al., 1996), ovine (Borowczyk et al., 2007) and cats 
(Arikan and Yigit, 2009). It is also reported that incubation of rabbit ovarian fragments with dbcAMP stimulates steroid synthesis (Sirotkin et al., 2014). However, response of the cells to the treatment varies depending on both the breed studied and the dose of dbcAMP used. It is not known how goat luteal cells respond to the cAMP treatment. Thus, it is important to examine the effects of dbcAMP on steroidogenesis in goat luteal cell subpopulations isolated from early and late luteal phase corpora lutea. Therefore, present study is aimed to examine interaction among luteal age, luteal cell type, cAMP, and steroid synthesis.

\section{Materials and Methods}

\section{Animals and tissue collection}

Animals used in the present study were purchased from an Angora goat breeder. The research proposal has been reviewed and approved by the local ethics committee. Eight healthy adult female goats (3-4 years old and $35-40 \mathrm{~kg}$ ) were randomly selected into two groups in separate pens throughout breeding season (the period between August to March) in Kirıkkale (latitude $39^{\circ} 52^{\prime} 45.6^{\prime \prime} \mathrm{N}$, longitude $33^{\circ} 26^{\prime} 45.1^{\prime \prime} \mathrm{E}$ ). A fertile billy goat was also accommodated in a third pen located between two pens of female goats for monitoring estrus cycle. To avoid mating, the abdominal region of the male goat was covered. Corpora lutea were surgically removed from the animals following laparoscopy on early (5th day) and late (15th day) luteal phase of the estrous cycle. Immediately (within $15 \mathrm{~min}$ ) after surgical operation, the luteal tissues were transported to the laboratory in an ice-cold sterile medium containing $100 \mathrm{IU} / \mathrm{ml}$ penicillin, $100 \mu \mathrm{g} / \mathrm{ml}$ streptomycin, and $2.5 \mu \mathrm{g} / \mathrm{ml}$ fungizone (Arikan et al., 2010).

\section{Luteal cell preparation}

All chemical compounds used in preparation of cells were purchased from Sigma Chemical Company (Sigma-Aldrich, Co., Munich, Germany). All processes carried out during cell preparation were performed on laminar flow hood under sterile conditions. Luteal tissue was dispersed by collagenase digestion as previously described (Kalender and Arikan, 2007; Arikan et al., 2010) with minor modifications. Briefly, the luteal tissue was sliced into very small pieces after decapsulating corpora lutea. Sliced tissues were then transferred to an erlenmeyer flask for cell dissociation. The cells were then dissociated by four consecutive $1 \mathrm{~h}$ incubations at $37^{\circ} \mathrm{C}$ in a shaking water bath $(90$ cycles/min) in the aerated (with oxygen for $2 \mathrm{~min}$ ) nutrient culture medium comprising $0.2 \%$ collagenase, $0.005 \%$ DNase, $0.5 \%$ bovine serum albumin (BSA), $100 \mathrm{IU} / \mathrm{ml}$ penicillin, $100 \mu \mathrm{g} / \mathrm{ml}$ streptomycin, and 2.5 $\mu \mathrm{g} / \mathrm{ml}$ fungizone. Undigested tissue fragments were removed from the dissociated cells by filtering the pooled supernatants from four incubations through a cell strainer $(100 \mu \mathrm{m}, \mathrm{BD}$ Biosciences, San Jose, CA, USA). Cells were then resuspended in phosphate buffered saline (PBS).

\section{Cell fractionation}

Percoll (Sigma-Aldrich, Co.) was used for the purpose of purification and fractionation of luteal cells by density gradient centrifugation. Cell fractionation was performed as previously described (Brannian, 1997; Arikan et al., 2010). Briefly, percoll gradients of 10, 20 and 40\% (densities $=1.0188,1.0318$ and $1.0578 \mathrm{~g} / \mathrm{ml}$, respectively) were prepared in $15 \mathrm{ml}$ conical centrifuge tubes. Cells suspended in PBS $(4 \mathrm{ml})$ were gently stratified on top of the discontinuous percoll gradient. Tubes were centrifuged on a fixed angle rotor at $400 \mathrm{~g}$ for $20 \mathrm{~min}$. Blood cells were located at the bottom of the tubes. In contrast, cell debris was fractionated on top of $10 \%$ interphase. Two luteal cell fractions were recovered from the $10 / 20 \%$ (small luteal cell enriched) and 20/40\% (large luteal cell enriched) interphases. Finally, in order to remove percoll, pooled cells were washed with culture medium. Trypan blue was used to determine cell viability.

\section{Culturing of luteal cell subpopulations}

Cell counting was based on steroidogenic lutal cells that were identified by staining cells for $3 \beta-H S D$ activity (Payne et al., 1980; Arikan and Yigit, 2002). Then, the cells were incubated as previously described by Arikan et al., 2010. Briefly, after counting steroidogenic cells on a hemocytometer, the cells $\left(5 \times 10^{4}\right.$ cells (well) were cultured in a humidified incubator (Binder GmbH, CB150, Tuttlingen, Germany), containing a mixture of $5 \% \mathrm{CO}_{2}$ and $95 \%$ air. Incubation of cells was carried out in plastic culture dishes (six-well) that include $2 \mathrm{ml}$ medium [DMEM/F-12 with $15 \mathrm{mM}$ HEPES containing $10 \%$ foetal bovine serum, penicillin (100 IU/ml), streptomycin $(100 \mu \mathrm{g} / \mathrm{ml})$ and fungizone $(2.5 \mu \mathrm{g} / \mathrm{ml})]$ in each well. Cells were permitted to attach to tissue culture plate without any treatment for the first $18 \mathrm{~h}$. Thereafter, cells were cultured in a serum-free medium supplemented with ITS premix $(10 \mu \mathrm{g} / \mathrm{ml}$ insulin, $5.5 \mu \mathrm{g} / \mathrm{ml}$ transferrin and $5 \mathrm{ng} / \mathrm{ml}$ sodium selenite) throughout culture for periods of up to 7 days.

Luteal cells, which were isolated from early luteal phase corpora lutea, were treated with dbcAMP $(0.1 \mathrm{mM}$ and $1 \mathrm{mM})$ in the absence or presence of 22R-HC for 7 days. Media were collected every $48 \mathrm{~h}$ and stored at $-20^{\circ} \mathrm{C}$. Progesterone levels in the conditioned medium were determined by using commercial progesterone RIA kits (BioSource Europe SA, Nivelles, Belgium). The limit of assay sensitivity was $0.06 \mathrm{ng} / \mathrm{ml}$ and the intra- and interassay coefficients of variation were 4.4 and $8.8 \%$, respectively. The recovery varied between 93 and 105\%.

\section{Statistical analysis}

All results are reported as mean \pm SEM of four independent experiments for each treatment group. Steroid synthesis was expressed as ng/50.000 cells. All statistical analyses were carried out with SPSS 14.0 (SPSS, Chicago, IL, USA). Different treatments were assessed by ANOVA followed by Duncan test for 
multiple comparisons when appropriate.

\section{Results}

\section{Monitoring cell morphology}

Determining $3 \beta$-HSD activity in fresh cell suspension allows identifying the steroidogenic luteal cells. Occurring mostly in clumps, non-steroidogenic cells were stained negative for $3 \beta$-HSD activity. In contrast, stained steroidogenic luteal cells usually lined individually (Fig. 1). This process allowed us to exclude non-steroidogenic cells during the cell counting process.

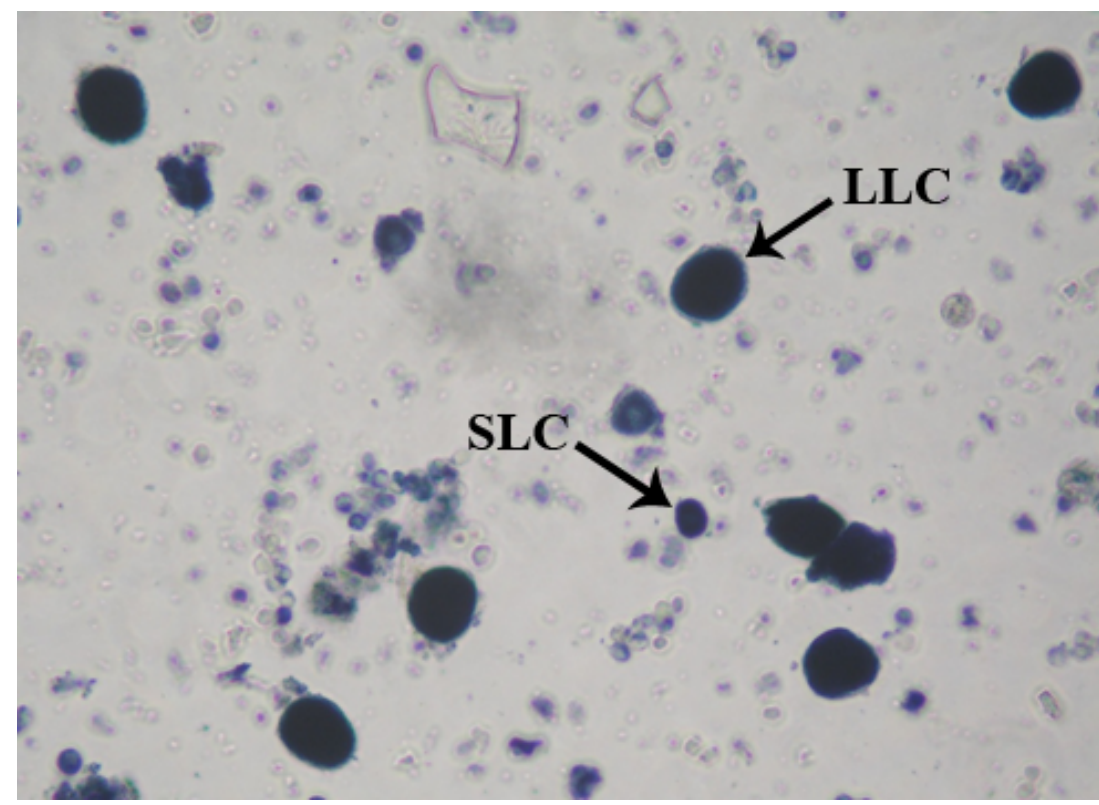

Figure 1. Picture of stained cells for $3 \beta$-HSD activity in cell suspension before incubation. (200X). LLC: Large luteal cell, SLC: Small luteal cell.

In order to monitor cell attachment and growth, cells on the bottom of the culture plate were also stained during incubation. Apart from the cell nucleus, during the cell growth we observed that the round shape of the cells change to elliptical. In addition to this, cell membrane protruded between the nearest cells during the cell growth (Fig. 2). Any cell damage or poor cell development could easily be monitored on the bottom surface of the plate after staining cells for $3 \beta$-HSD activity.

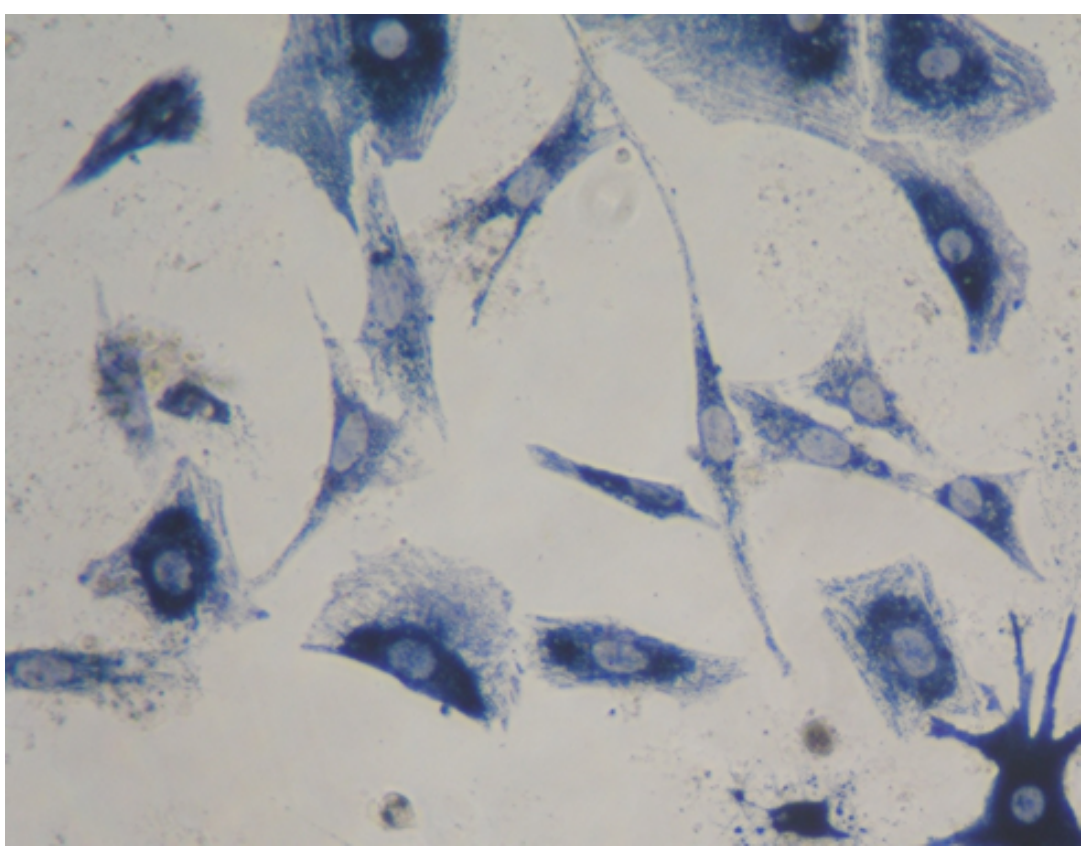

Fig. 2. Picture of stained cells for $3 \beta$-HSD activity on the bottom surface of the plastic tissue culture plate on day 7 of incubation $(\mathrm{x} 400)$. 
Effect of dbcAMP on progesterone accumulation by cells isolated from early luteal phase corpora lutea

Luteal cells maintained steroidogenic capacity in all groups of 22R-HC treated cells throughout culture periods. In contrast, as incubation time increased, steroid synthesis decreased in all groups of untreated cells. The cells treated with $22 \mathrm{R}-\mathrm{HC}$ alone resulted in significant stimulation $(\mathrm{P}<0.01)$ on progesterone synthesis in all treatment.

Treating cells with dbcAMP without 22R-HC resulted in a higher progesterone synthesis $(\mathrm{P}<0.05)$ in comparison with the untreated groups on the 5 th day of estrous cycle (Fig. 3). The stimulation varied between 1.50 to 2.50 times. In contrast, increase in progesterone synthesis in one of the groups treated with $0.1 \mathrm{mM}$
dbcAMP failed to reach a significant level $(\mathrm{P}>0.05)$ on the 3 rd day of the incubation of cells collected from $20 / 40 \%$ of percoll layers (Fig. 3b).

Treating the cells with cholesterol showed a 4 to 8.50 times increase in progesterone accumulation in comparison to the control cells. Significant stimulation in steroid synthesis was seen in cells treated with $1 \mathrm{mM}$ dbcAMP + 22R-HC during every treatment day. However, treatment of cells with $0.1 \mathrm{mM}$ dbcAMP + 22R-HC failed to cause a significant effect on progesterone synthesis except on the 5th day of the incubation of cells collected from $20 / 40 \%$ of percoll layers (Fig. 3b). By the 7th day, basal progesterone production, in cells collected from $10 / 20 \%$ and $20 / 40 \%$ of percoll layer, decreased to 50 and $59 \%$ of starting value, respectively (Fig. 3).
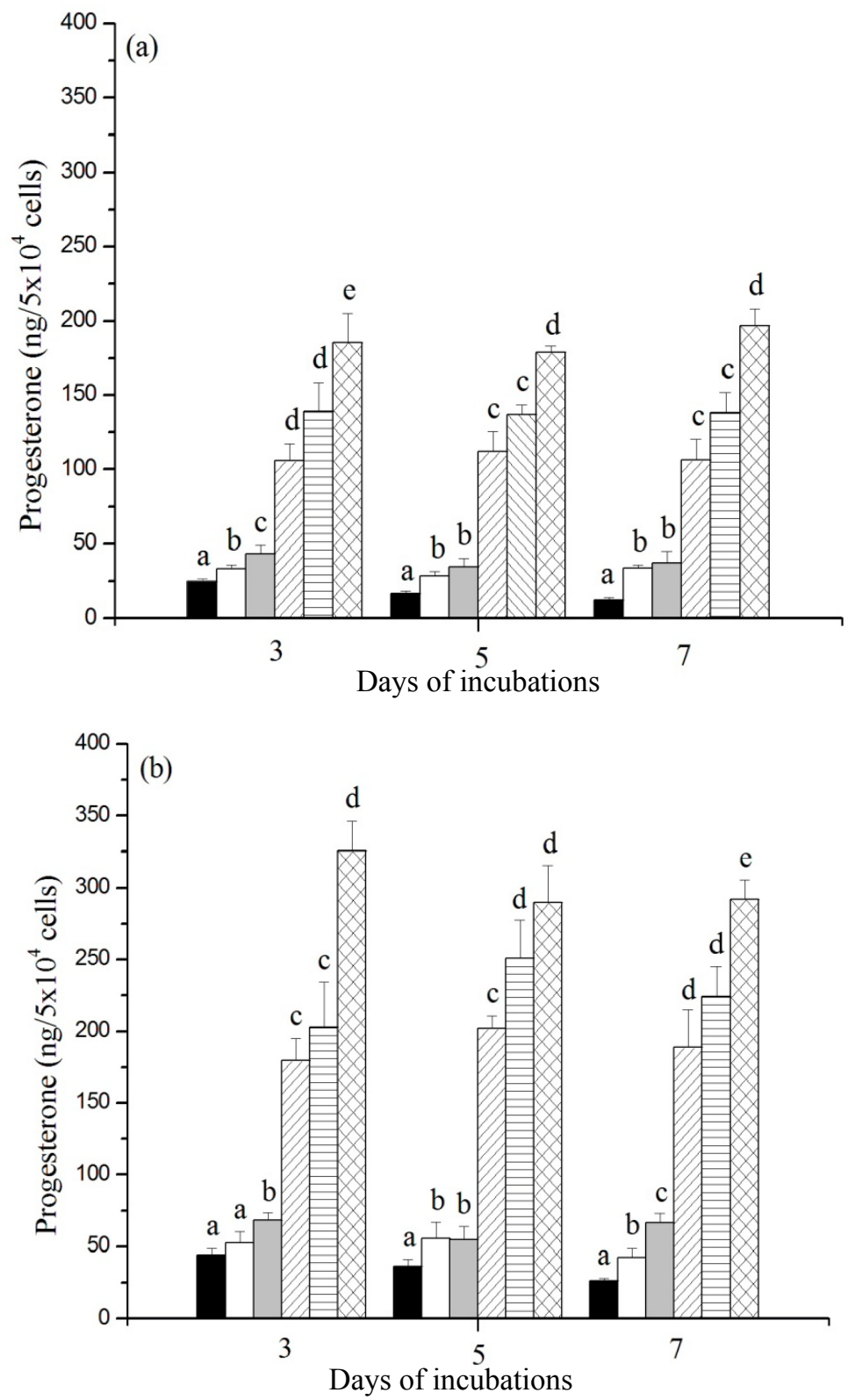

Figure 3. The effect of dbcAMP on progesterone synthesis by cells isolated from early luteal phase corpora lutea. (a) Incubated cells were harvested from $1120 \%$ of percoll layers (b) Incubated cells were harv ested from 20/40\% of percoll layers. Control $(\square), 0.1 \mathrm{mM}$ dbcAMP $(\square), 1 \mathrm{mM}$ dbcAMP $(\square), 10 \mu \mathrm{g} / \mathrm{ml} 22 \mathrm{R}-\mathrm{HC}(\square), 10 \mu \mathrm{g} / \mathrm{ml} 22 \mathrm{R}-\mathrm{HC}+$ $0.1 \mathrm{mM}$ dbcAMP (目), $10 \mu \mathrm{g} / \mathrm{ml}$ 22R-HC $+1 \mathrm{mM}$ dbcAMP (囚). Results are the mean \pm SEM of 4 separate experiments. Groups with different letters above standard error bars are significantly different within each day $(\mathrm{P}<0.05)$. 
Effect of dbcAMP on progesterone accumulation by cells isolated from late luteal phase corpora lutea

Two different doses of dbcAMP $(0.1$ and $1 \mathrm{mM})$ were used to treat the cells. Treating cells with $1 \mathrm{mM}$ dbcAMP in the absence or presence of 22R-HC increased $(\mathrm{P}<0.01)$ progesterone accumulation significantly. In contrast, treatment of cells with $0.1 \mathrm{mM}$ dbcAMP did not have a significant effect $(\mathrm{P}>0.05)$ on progesterone synthesis in any treated group (Fig. 4).
Treating cells only with cholesterol resulted in a 4.40 to 11.60 times increase in progesterone accumulation in comparison to the untreated cells. In comparison to the cells collected from 10/20\% of percoll layers, the cells collected from $20 / 40 \%$ of percoll layers produced more progesterone, in $22 \mathrm{R}-\mathrm{HC}$ untreated cell groups. In addition, progesterone synthesis was decreased as incubation time increased in all the groups of untreated cells throughout culture (Fig. 4).
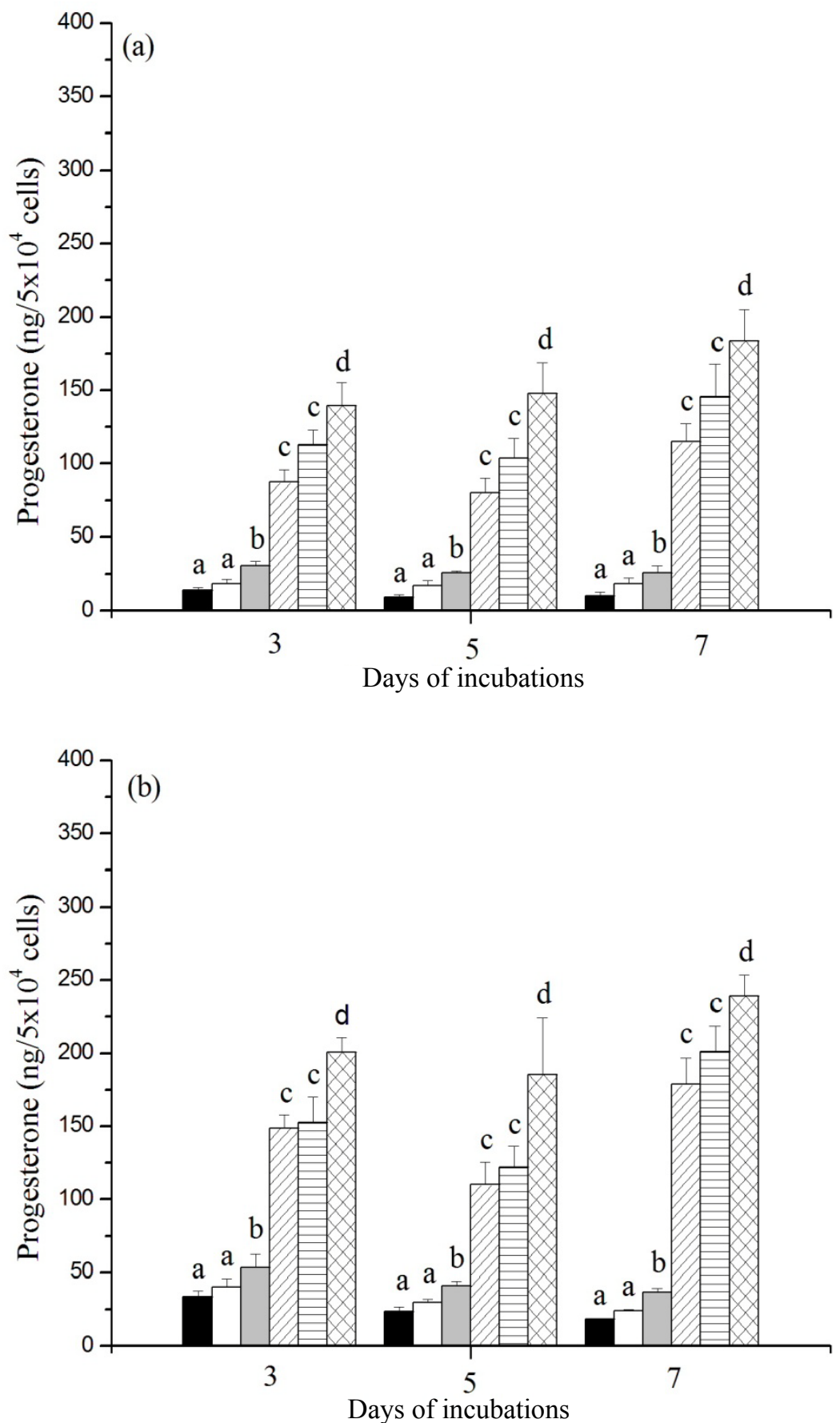

Figure 4. The effect of dbcAMP on progesterone synthesis by cells isolated from late luteal phase corpora lutea. (a) Incubated cells were harvested from $1120 \%$ of percoll layers (b) Incubated cells were harvested from 20/40\% of

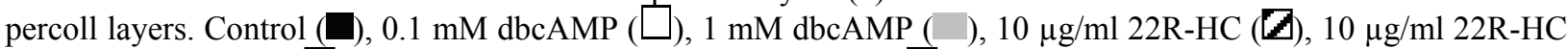
$+0.1 \mathrm{mM}$ dbcAMP (目), $10 \mu \mathrm{g} / \mathrm{ml}$ 22R-HC $+1 \mathrm{mM}$ dbcAMP (目). Results are the mean \pm SEM of 4 separate experiments. Groups with different letters above standard error bars are significantly different within each day $(\mathrm{P}<0.05)$. 


\section{Discussion}

This is the first study regarding cAMP effects on luteal steroidogenesis in goats. Since response of luteal cells to the exogenous treatments might be affected by age and type of luteal cells, we used small and large luteal enriched subpopulations from early and late luteal corpora lutea as cell sources in this study.

In the present study, progesterone production was stable in the cholesterol treated group during the 7 days of culture period. However, contrary to this, the cholesterol levels were decreased over time in the control groups. A similar decrease in luteal progesterone synthesis was reported in various cell culture studies performed without cholesterol treatment on sheep (Grazul-Bilska et al., 1996), bovine (O’Shaughnessy and Wathes, 1985b; Arikan and Rodway, 2000) and goats (Arikan et al., 2010). On the 3rd day, no significant difference was found in terms of steroid synthesis between cells isolated from corpora lutea collected on early and late luteal stages. In vivo goat studies, in which similarities in terms of plasma progesterone contents were reported on the 5th and 15th days of the oestrus cycle, support this result (Medan et al., 2003; Gaafar et al., 2005). As expected, the effect of cholesterol was stimulatory in all cases. Cholesterol supply is an obvious factor in the control of the steroidogenesis rate as it is the precursor of progesterone (O'Shaughnessy and Wathes, 1985b). Depending on the type of incubated cells, luteal age and days of incubation, a 4.00 to 11.60 times increase in progesterone production is seen in the incubation of luteal cells with 22R-HC. Studies on ovine (Fitz et al., 1993), bovine (Arikan and Rodway, 2000), goats (Arikan et al., 2010), porcine (Brannian et al., 1995) and feline (Arikan and Yigit, 2009) support this result.

In this study, significant increase in luteal progesterone synthesis was induced with cells being treated with dbcAMP. Incubation of the cells with cAMP induced up to 2.98 times increase in progesterone release depending on used doses, cell types, luteal stage and days of incubation. Earlier studies also demonstrated that dbcAMP stimulated progesterone release in cultured cells isolated from corpora lute of rat (Tekpetey and Armstrong, 1991), bovine (O'Shaughnessy and Wathes, 1985a; GrazulBilska et al., 1996), ovine (Borowczyk et al., 2007), cats (Arikan and Yigit, 2009) and human (Carrascol et al., 1996). However, response of the cells to the treatment varies depending both on the dbcAMP dose used and on the breed studied. A 3.8 times increase in the progesterone synthesis has been reported in the incubation of midluteal bovine luteal cells with dbcAMP (1 mM; Grazul-Bilska et al., 1996). In another study, a 2 time increase in progesterone release was reported in which the same dose of $1 \mathrm{mM}$ dbcAMP was used for the incubation of ovine luteal cells collected on the 5th day of the estrus cycle (Borowczyk et al., 2007). It is also reported that, in a culture of bovine luteal cells, dbcAMP (1 mM) might act to maintain progesterone synthesis at least for 7 days (O'Shaughnessy and Wathes, 1985a). This study supports our present results, in which goat luteal cells continued to produce progesterone for the 7 day incubation under the dbcAMP effect.

In conclusion, large luteal cell enriched subpopulations produced more basal progesterone than did the cells of small luteal cell enriched subpopulations. As expected, incubation of cells with 22R-HC induced a significant positive effect on progesterone synthesis. Both in the early and late luteal cell subpopulations, steroid synthesis was correlated with doses of cAMP. However, cAMP stimulated progesterone levels did not reach significant levels when cell is treated with $0.1 \mathrm{mM}$ cAMP plus cholesterol.

\section{Acknowledgments}

The Scientific and Technological Research Council of Turkey (TUBITAK) financially supported the present study. Project No: TOVAG-108O520.

\section{References}

Arikan S, Rodway RG. 2000. Effects of high density lipoprotein containing high or low [beta]-carotene concentrations on progesterone production and [beta]carotene uptake and depletion by bovine luteal cells. Anim Reprod Sci, 62:253-263.

Arikan S, Yigit AA. 2002. Size distribution of steroidogenic and non-steroidogenic ovine luteal cells throughout pregnancy. Anim Sci, 75:427-432.

Arikan S, Yigit AA. 2003. Changes in the size distribution of goat steroidogenic luteal cells during pregnancy. Small Rumin Res, 47:227-231.

Arikan S, Yigit AA. 2009. Effects of cholesterol and cAMP on progesterone production in cultured luteal cells isolated from pseudopregnant cat ovaries. Anim Reprod Sci, 115:238-246.

Arikan S, Kalender H, Simsek O. 2010. Effects of cholesterol on progesterone production by goat luteal cell subpopulations at two different stages of the luteal phase. Reprod Domest Anim, 45:e434-439.

Band V, Kharbanda SM, Murugesan, SM, Farooq A. 1987. Steroid production in vitro by granulosa, theca, and luteal cells from goat ovaries. Biol Reprod, 36:799806.

Bao B, Thomas MG, Griffith MK, Burghardt RC, Williams GL. 1995. Steroidogenic activity, insulin-like growth factor-I production, and proliferation of granulosa and theca cells obtained from dominant preovulatory and nonovulatory follicles during the bovine oestrous cycle: Effects of low-density and high density lipoproteins. Biol Reprod, 53:1271-1279.

Borowczyk E, Johnson ML, Bilska MA, Redmer DA, Reynolds LP, Grazul-Bilska AT. 2007. Role of gap junctions in regulation of progestrone secretion by ovine luteal cells in vitro. Reproduction, 133:641-651.

Brannian JD, Christianson H, Flynn S, Kurz SG. 1995. Loss of low-density lioprotein utilization by regressing porcine luteal cells: effects of protein kinase C activation. Biol Reprod, 52:793-797. 
Brannian JD. 1997. Expression and function of a scavenger lipoprotein pathway in porcine luteal cells Biol Reprod, 56:221-228.

Carrascol I, Troncoso JL, Devoto L, Vega M. 1996. Differential steroidogenic response of human luteal cell subpopulations. Hum Reprod, 11:1609-1614.

Chegini N, Ramani N, Rao CV. 1984. Morphological and biochemical characterisation of small and large bovine luteal cells during pregnancy. Mol Cell Endocrinol, 37:89-102.

Fields MJ, Fields PA. 1996. Morphological characteristics of the bovine corpus luteum during the oestrous cycle and pregnancy. Theriogenology, 45:1295-1325.

Fitz TA, Contois DF, Marr MM, Rexroad CE, Fritz MA. 1993. Effects of substrate supplementation with hydroxycholesterol analogues and serum lipoproteins on ovine luteal cell progesterone secretion in vitro: demonstration of prostaglandin F2 luteolytic actions in a defined model system. J Reprod Fertil, 97:57-63.

Gaafar KM, Gabr MK, Teleb DF. 2005. The hormonal profile during the estrous cycle and gestation in Damascus goats. Small Rumin Res, 57:85-93.

Grazul-Bilska AT, Reynolds LP, Kirsch JD, Redmer DA. 1996. Gap junctional intercellular communication of bovine luteal cells from several stages of estrous cycle: effect of cyclic adenosine 3', 5' -monophosphate. Biol Reprod, 54:538-545.

Kalender H, Arikan S. 2007. Size distribution of dispersed luteal cells during oestrous cycle in Angora goats. Reprod Domest Anim, 42:457-460.

Lei ZM, Chegini N, Rao CHV. 1991. Quantitative cell composition of human and bovine corpora lutea from various reproductive states. Biol Reprod, 44:1148-1156.

Medan MS, Watanabe G, Sasaki K, Sharawy S, Groome NP, Taya K. 2003. Ovarian dynamics and their associations with peripheral concentrations of gonadotropins, ovarian steroids, and inhibin during the estrous cycle in goats. Biol Reprod, 69:57-63.

Musicki B, Aten RF, Behrman HR. 1994. Inhibition of protein synthesis and hormone-sensitive steroidogenesis in response to hydrogen peroxide in rat luteal cells. Endocrinology, 134:588-595.

O'Shaughnessy PJ, Wathes DC. 1985a. Characteristics of bovine luteal cells in culture: morphology, proliferation and progesterone secretion in different media and effects of $\mathrm{LH}$, dibutyryl cyclic AMP, antioxidants and insulin. J Endocrinol, 104:355361.

O'Shaughnessy PJ, Wathes DC. 1985b. Role of lipoproteins and de-novo cholesterol synthesis in progesterone production by cultured bovine luteal cells. J Reprod Fertil, 74:425-432.

O'Shea JD. 1987. Heterogeneous cell types in the corpus luteum of sheep, goats and cattle. J Reprod Fertil Suppl, 34:71-75.

O'Shea JD, Rodgers RJ, D'Occhio MJ. 1989. Cellular composition of the cyclic corpus luteum of the cow. $J$ Reprod Fertil, 85:483-487.

Payne AH, Downing JR, Wong KL. 1980. Luteinizing hormone receptors and progesterone synthesis in two distinct populations of Leyding cells. Endocrinology, 106:1424-1429.

Sirotkin AV, Balazi A, Chrenek P. 2014. The cAMP analogue, dbcAMP, affects rabbit ovarian cell proliferation, apoptosis, release of steroids and response to hormones. Folia Biol (Krakow), 62:211-218.

Tekpetey FR, Armstrong DT. 1991. Steroigenic response of rat and pig luteal cells to estradiol-17 $\beta$ and catecholestrogens in vitro. Biol Reprod, 45:498-505.

Vitic J, Stevanovic J. 1993. Comparative studies of the serum lipoproteins and lipids in some domestic, laboratory and wild animals. Comp Biochem Physiol B Biochem Mol Biol, 106:223-229. 